\title{
Impact of Helicobacter pylori on the growth of hepatic orthotopic graft tumors in mice
}

\author{
JUNWEI WANG ${ }^{1-3}$, XIAOQIAN WANG ${ }^{3}$, NANHONG TANG $^{3}$, YANLING CHEN $^{1,3}$ and FEIFEI SHE ${ }^{1,2}$ \\ ${ }^{1}$ Key Laboratory of Ministry of Education for Gastrointestinal Cancer, School of Basic Medical Sciences, \\ Fujian Medical University, Fuzhou, Fujian; ${ }^{2}$ Key Laboratory of Tumor Microbiology, School of Basic Medical Sciences, \\ Fujian Medical University, Fuzhou, Fujian; ${ }^{3}$ Department of Hepatobiliary Surgery, Fujian Medical University \\ Union Hospital, Fuzhou, Fujian 350001, P.R. China
}

Received April 8, 2015; Accepted May 25, 2015

DOI: $10.3892 /$ ijo.2015.3107

\begin{abstract}
Helicobacter pylori is a well-known causative organism of chronic gastric diseases and has been found in many hepatic carcinoma samples. To explore the expression of apoptosis-related proteins and carcinoma development in $H$. pylori-infected livers, we utilized BALB/cAnSlac mice to establish an $H$. pylori-infected model by oral inoculation and orthotopic grafts of hepatic tumors by $\mathrm{H} 22$ cells, respectively. We found that $H$. pylori colonies could not be cultured from all liver and tumor samples. However, its $16 \mathrm{~S}$ rRNA was detectable in $85.3 \%$ of livers and $66.7 \%$ of tumors in the infected mice. Inflammatory cells were observed and thinly distributed in the lobule portions of the liver, and $H$. pylori mainly existed in the infected hepatic sinusoids and the necrotic areas of the infected tumors. No significant difference was found in liver to body weight ratio between the infected and uninfected. Moreover, the pathological tumor difference was unremarkable between the two. The proliferating cell nuclear antigen (PCNA) and Bcl-2associated $\mathrm{X}$ protein (Bax) expression in the infected tumors was significantly higher and lower, respectively, than those of the uninfected tumors. However, no significant difference in Bcl-2 (B-cell lymphoma 2) expression existed. The results indicate that H.pylori found in the livers which were infected by H.pylori oral inoculation could contribute to the infiltration of inflammatory cells in livers. Although $H$. pylori has no significant impact on
\end{abstract}

Correspondence to: Professor Feifei She, Key Laboratory of Tumor Microbiology, School of Basic Medical Sciences, Fujian Medical University, 1 Xueyuan Road, Fuzhou, Fujian 350001, P.R. China

E-mail: shefeifei@yeah.net

Professor Yanling Chen, Department of Hepatobiliary Surgery, Fujian Medical University Union Hospital, 29 Xinquan Road, Fuzhou, Fujian 350001, P.R. China

E-mail: ylchen@medmail.com.cn

Abbreviations: H.pylori, Helicobacter pylori; PCNA, proliferating cell nuclear antigen; Bcl-2, B-cell lymphoma 2; Bax, Bcl-2associated $\mathrm{X}$ protein

Key words: H. pylori, hepatic tumor, PCNA, Bcl-2, Bax the liver to body weight ratio or tumor Bcl-2 expression, it may upregulate PCNA expression and downregulate Bax expression, respectively. All our findings show that $H$. pylori may promote proliferation and inhibit apoptosis of tumor cells.

\section{Introduction}

As one of the most common pathogens in human bacteriarelated chronic infection and carcinomatous diseases, Helicobacter pylori infects almost $50 \%$ of the world population (1). In 1994, the World Health Organization (WHO) and International Agency for Research on Cancer (IARC) classified it as a type I carcinogen (2). It has been reported that $H$. pylori plays a crucial role in the occurrence and development of chronic active gastritis, peptic ulcers, mucosaassociated lymphoid tissue lymphoma (MALT) and even gastric adenocarcinoma (3). Moreover, H. pylori is also closely related to some hematological systemic disorders, for example, hypoferric anemia and idiopathic thrombocytopenic purpura. Recently, it was demonstrated that it is involved in extragastric diseases such as atherosclerosis, ischemic heart disease, immunologic dysfunction, migraines and pediatric growth retardation (4-7). According to abundant clinical studies which had demonstrated morphological and molecular biological evidence, the infection rate of $H$. pylori is higher in patients with chronic hepatic diseases such as chronic hepatitis, liver cirrhosis and liver cancer than the rate of healthy persons (8-14). Xuan et al (14) even positively cultured $H$. pylori in $3(10.7 \%)$ of their 28 primary hepatic carcinoma patients.

Primary hepatic cancer is an epidemic malignant tumor worldwide, and $\sim 665,000$ new cases are diagnosed every year (15). With an extremely high mortality rate, it ranks second as a cancer-related cause of death and is responsible for 746,000 deaths worldwide in 2012 (16). Its 5-year survival rate in developed countries, such as the United States, is 9\% (15), whereas $<5 \%$ worldwide (17), due to its high postoperative recurrence rate and poor prognosis $(18,19)$. Thus, interference from the source is the most effective measure that might etiologically prevent the occurrence and development of primary hepatic cancer. Hepatitis B virus, hepatitis $C$ virus, aflatoxin, chemical carcinogens and parasitic infections have been identified as pathogenic factors in primary hepatic cancer (20-22). 
However, basing on the discovery that $H$. pylori was found in the liver of patients who suffered from chronic hepatic diseases, researchers have proposed that it plays a role in hepatitis and hepatic cancer. This novel hypothesis prompted studies concerning the correlation between $H$. pylori and hepatic cancer $(23,24)$. The findings may also be helpful in prophylaxis and treatment of hepatic cancer.

Ito et al (25), Zhang et al (26) and Chen et al (27) co-cultured human hepatoma cells with $H$. pylori in vitro and determined the interaction of $H$. pylori with hepatocyte surface molecular receptors. $H$. pylori adhered to and invaded hepatoma cells. As a result, it caused a cytotoxic effect that upregulated tumor-related cyclin D1 and PCNA (proliferating cell nuclear antigen). However, they mainly performed studies in vitro that could hardly simulate the microenvironment of liver in vivo. Thus, the function of $H$. pylori in liver cancer remains unclear. In the present study, BALB/cAnSlac mice were orally inoculated with an infective dose of $H$. pylori. Then, we developed a tumor-bearing mouse model. Finally, we evaluated the infection status and explored the role of $H$. pylori in the development of hepatic cancer.

\section{Materials and methods}

Animals. Six to eight weeks old male and female specificpathogen-free (SPF) BALB/cAnSlac mice whose fecal DNA were determined by C97/C98 Helicobacter spp. primers were obtained from Slaccas Laboratory Animal Co., Ltd., (Shanghai, China; License no. SCXK 2002-0003, Certificate no. 2007000551273) and housed under SPF conditions in Fujian Medical University Laboratory Animal Center (Fuzhou, China; License no. SYXK 2012-0001). All the following pathogens were excluded from SPF BALB/cAnSlac mice [SPF Laboratory Animal Standard of the People's Republic of China (GB 14922.2-2011)]. Salmonella spp.; Yersinia pseudotuberculosis; Yersinia enterocolitica; Pathogenic dermal fungi; Streptobacillus moniliformis; Bordetella bronchiseptica; Mycoplasma spp.; Corynebacterium kutscheri; Tyzzer's organism; Escherichia coli O115 a, C, K (B); Pasteurella pneumotropica; Klebsiella pneumonia; Staphylococcus aureus; Streptococcus pnemoniae; $\beta$-hemolytic streptococcus; Pseudomonas aeruginosa; lymphocytic choriomenigitis virus (LCMV); hantavirus (HV); ectromelia virus (Ect.); mouse hepatitis virus (MHV); sendai virus (SV); pneumonia virus of mice (PVM); reovirus type III (Reo-3); minute virus of mice (MVM); Theiler's mouse encephalomyelitis virus (TMEV); mouse adenovirus (Mad); polyomavirus (POLY); rat parvovirus (KRV); rat parvovirus (H-1); rat coronavirus $(\mathrm{RCV}) /$ sialodacryoadenitis virus (SDAV). All mice were fed a sterilized commercial diet, given water ad libitum, and allowed to acclimatize for at least 1 week before the experiments. All animal protocols met the approval of the Institutional Animal Care Committee.

Bacterial strains and culture conditions. H. pylori type strain NCTC 11637 (National Institute For Communicable Disease Control And Prevention, Chinese Center For Disease Control And Prevention, Beijing, China) was used in the present study. Columbia agar base was used (Oxoid Ltd., Hampshire, UK) that was supplemented with $8 \%$ sheep blood (Bio-Kont Technology Co., Ltd., Xiamen, China) and H. pylori selective supplements (Oxoid) containing vancomycin $(0.01 \mathrm{mg} / \mathrm{ml})$, cefsulodin $(0.5 \mathrm{mg} / \mathrm{ml})$, trimethoprim $(0.5 \mathrm{mg} / \mathrm{ml})$ and amphotericin B $(0.5 \mathrm{mg} / \mathrm{ml})$. The bacteria were incubated in microaerophilic conditions $\left(5 \% \mathrm{O}_{2}, 10 \%\right.$ $\mathrm{CO}_{2}, 85 \% \mathrm{~N}_{2}, 37^{\circ} \mathrm{C}$, humidity $>90 \%$; LEEC Touch $190 \mathrm{~S}$; LEEC Ltd., Nottingham, UK) and harvested in sterile phosphate-buffered saline (PBS) after $48 \mathrm{~h}$ of growth, centrifuged at $4000 \mathrm{x} \mathrm{g}$ for $2 \mathrm{~min}$, and adjusted in sterile PBS to a final concentration of $5 \times 10^{9}$ colony-forming units per milliliter (CFU/ml). Additionally, H. pylori was not only assessed by Gram staining and phase microscopy for purity, morphology and motility, but also tested for urease, catalase and oxidase activity before any animal experiments.

Cell line and cultivation. $\mathrm{H} 22$ murine hepatic hepatoma cells were obtained from China Center for Type Culture Collection (Wuhan, China) and syngeneic to BALB/cAnSlac mice. The cells were initially grown in a complete RPMI-1640 medium (HyClone Laboratories Inc., Logan, UT, USA) containing $10 \%$ fetal bovine serum (FBS) at $37^{\circ} \mathrm{C}$ and $5 \% \mathrm{CO}_{2}$ in vitro for 2-3 days. Subsequently, the cell suspension was tested for Helicobacter and other microorganisms prior to mouse injection or implantation. The cell suspension was spread evenly over Columbia agar base and kept in microaerophilic condition for microaerophilic bacteria detection. So did the Luria-Bertani base in usual condition $\left(37^{\circ} \mathrm{C}\right)$ for aerobic bacteria detection. Additionally, after centrifugation the DNA was extracted by Genomic DNA Mini extraction kit (Beyotime Institute of Biotechnology, Haimen, China) for Helicobacter genus-specific 16S rRNA (C97/C98) test. Under the circumstance that all detection methods above were negative for microorganisms, we conducted the further protocols. The cell suspension was collected and centrifuged at $2000 \mathrm{x} \mathrm{g}$ for $5 \mathrm{~min}$ and adjusted with a serum-free RPMI-1640 medium to a final concentration of $1 \times 10^{7} / \mathrm{ml}$. Every BALB/cAnSlac mouse was intraperitoneally injected with a $0.2-\mathrm{ml}$ cell suspension for the first in vivo subcultivation for a 7-day period. Finally, the mouse was euthanized by cervical dislocation, and its ascites was collected and centrifuged. Ascitic precipitate cells were washed and adjusted to the same concentration. The cell suspension was intraperitoneally injected into another BALB/cAnSlac mouse for the second in vivo subcultivation. Following similar, previously discussed protocols, a third in vivo subcultivation was performed. Then, the centrifuged cells were adjusted to $4 \times 10^{7} / \mathrm{ml}$ and were used in an orthotopic implantation.

Drug pretreatment. Lactobacilli which inhabit the stomachs of the mice would interfere with the growth of $H$. pylori even eradicate it (28). All 70 experimental mice were treated on the 1 st to 3 rd day with the drugs listed in Table I, according to the methods described by Thalmaier et al (29). A mixed solution of ciprofloxacin (Zhejiang Jingxin Pharmaceutical, Co., Ltd., Zhejiang, China), amikacin (Shanghai Harvest Pharmaceutical Co., Ltd., Shanghai, China), imipenem (Merck Sharp \& Dohme Corp., Kenilworth, NJ, USA), vancomycin (Zhejiang Hisun Pharmaceutical Co., Ltd., Zhejiang, China), and fluconazole (Yangtze River Pharmaceutical Group, Taizhou, China) were administered once daily. 
Table I. Drugs and dose scheme ( $\mu \mathrm{g} / \mathrm{mouse} /$ day).

\begin{tabular}{lcc}
\hline Antibiotics & Oral dose & Intraperitoneal dose \\
\hline Ciprofloxacin & 500 & 0 \\
Amikacin & 375 & 375 \\
Imipenem & 1250 & 1250 \\
Vancomycin & 1000 & 1000 \\
Fluconazole & 150 & 0 \\
\hline
\end{tabular}

$\mu \mathrm{g}$, microgram

Infection protocols. On day 3 (after the last drug treatment), 70 mice were randomly divided into group A $(\mathrm{n}=40, \mathrm{H}$. pylori infected mice) and group B ( $=30$, uninfected mice). From 3rd to 9 th day, all mice were fasted for 15-18 h overnight before the treatment on the following day. The next day, every mouse was orally inoculated with a $0.2-\mathrm{ml}$ sterilized alkalescent buffer $(300 \mathrm{mM} \mathrm{NaHCO}$ ) to neutralize gastric acidity. Then, 15-30 min later, each mouse in group A was administered an oral $H$. pylori suspension $\left(1 \times 10^{9} \mathrm{CFU}\right.$; in $0.2 \mathrm{ml}$ of sterilized PBS) once daily for a continuous 7-day period (4th to 10th day; defined as the first week); group B was administered a $0.2-\mathrm{ml}$ sham dose of sterilized PBS in a same manner and schedule (30-32). All mice underwent hepatic surgery during the 9 th week.

Orthotopic hepatic carcinoma model. At the beginning of the 9 th week, the mice in group A were randomly divided into group A1 ( $\mathrm{n}=20 ; H$. pylori infected and tumor positive mice) and group A2 ( $\mathrm{n}=20 ; H$. pylori infected and tumor negative mice), and group B was divided into group B1 $(n=20$, uninfected and tumor positive mice) and group B2 $(\mathrm{n}=10$, uninfected and tumor negative mice). The left liver lobe of the mice was implanted with $50 \mu 1$ of $\mathrm{H} 22$ cell suspension $\left(2 \times 10^{6}\right.$ cells; mice in group A1 and B1) or just $50 \mu 1$ serum-free RPMI-1640 medium (mice in group A2 and B2) with a subcapsular intrahepatic injection according to Yao et al (33) and Aprahamian et al (34). Each mouse was anesthetized with $80 \mathrm{mg} / \mathrm{kg}$ ketamine (Sunkind Co., Ltd., Shanxi, China) by intraperitoneal injection. The mouse was placed in a supine position on the operating table when it was fully anesthetized. A small median longitudinal incision was made below the xiphoid to expose the left lobe of the liver, and sterile gauze was placed under it to prevent peritoneal sowing. $\mathrm{H} 22$ cells in a serum-free RPMI-1640 medium were slowly injected into the parenchyma of the left hepatic lobe at a 30-degree angle with a 100- $\mu 1$ microinjector (Shanghai Bolige Industry \& Trade Co., Ltd., Shanghai, China), thus, a transparent bleb of medium could be seen within the hepatic capsule. A sterile cotton swab was gently compressed on the injection site for hemostasis, and the abdomen was closed separately in a two layer method (peritoneum and skin) with a 4-0 silk suture. The mice were kept in SPF warm incubator for observation and finally returned to the SPF animal room when they had fully recovered from the anesthesia.
Tissue collection and bacterial isolation. The mice were fasted for $24 \mathrm{~h}$ overnight before necropsy. At the end of the 13 th week, all mice were euthanized by cervical dislocation and necropsied for bacterial isolation and histopathology. The hemorrhagic ascites was firstly collected from bulge abdomen of tumor positive mouse by a $2-\mathrm{ml}$ aseptically injector. The ascites was fully mixed and piped $(200 \mu \mathrm{l})$ onto the Columbia agar base for $H$. pylori culture in microaerophilic environment. The remainder was centrifuged at $4000 \mathrm{x} \mathrm{g}$ for $5 \mathrm{~min}$. The supernatant was tested for AFP ( $\alpha$-fetoprotein) by ELISA kit (Wuhan Boster Biological Technology, Co., Ltd., Wuhan, China) and compared with that in serum of both tumor positive and negative mouse. The DNA of cellular precipitate was extracted by Genomic DNA Mini extraction kit (Beyotime Institute of Biotechnology) and tested for Helicobacter genusspecific 16S rRNA (C97/C98). Samples of blood, stomach and liver were aseptically collected and cultured during necropsy. A total of $150 \mu \mathrm{l}$ of blood samples were collected from inferior vena cava puncture. One hundend microliters were spread evenly over a Columbia agar plate for $H$. pylori cultivation and $50 \mu \mathrm{l}$ were stored at $-80^{\circ} \mathrm{C}$ until for DNA and AFP analysis. The liver, as a whole, was removed and weighed. Then, the left liver lobe (group A2 and B2) was directly divided into three sections. The first section (50-100 mg) was ground in sterile grinders with $100 \mu 1$ of sterile PBS and spread evenly over a Columbia agar plate for $H$. pylori cultivation. The second section $(15 \times 15 \times 3 \mathrm{~mm})$ used for histological analysis was placed into $10 \%$ normal buffered formalin for $24 \mathrm{~h}$, and embedded in paraffin. Sections $(3-\mu \mathrm{m})$ were cut. The slides were stained with hematoxylin and eosin (H\&E; conducted by the Pathology Department of Affiliated Union Hospital of Fujian Medical University, Fuzhou, China) for assessment of histopathological changes and immunohistochemistry (IHC) staining for H.pylori, PCNA, B-cell lymphoma 2 (Bcl-2) and $\mathrm{Bcl}-2$-associated $\mathrm{X}$ protein (Bax). The third section was stored at $-80^{\circ} \mathrm{C}$ for DNA and protein analysis. Equally, the tumor in the left liver lobe (A1 and B1 group) was also divided, processed and analyzed as the protocols described above. Finally, the stomach was removed, opened along its greater curvature, and rinsed gently in sterile cold PBS. When the contents had been totally removed, the stomach was placed (mucosal side up) on sterile gauze and longitudinally dissected along the greater curvature into three fragments, so that each one contained the gastric cardia, body and antrum. The three gastric fragments were processed and analyzed. All Columbia agar plates were incubated in a microaerophilic condition $\left(5 \% \mathrm{O}_{2}, 10 \% \mathrm{CO}_{2}\right.$, $85 \% \mathrm{~N}_{2}$, humidity $>90 \%$ ) at $37^{\circ} \mathrm{C}$. The plates were evaluated for $H$. pylori growth from 3rd to 10 th day after necropsy. The presence of colonies were confirmed using morphology, Gram staining, biochemical tests (urease, catalase and oxidase reactions) and polymerase chain reaction (PCR). The plates were discarded and defined as negative if no positive colony was detected until the 10th day.

DNA extraction and PCR amplification. DNA of samples (blood, stomachs, livers and tumors) were isolated with Genomic DNA Mini extraction kit (Beyotime Institute of Biotechnology). According to the manufacturer's instruction, $25 \mathrm{mg}$ of tissue was completely triturated with an electric grinder (Tiangen Biotech, Co., Ltd., Beijing, China), 
and then, the homogenate (or $50 \mu \mathrm{l}$ of blood) was mixed in a vortex with $180 \mu \mathrm{l}$ of sample lysis buffer A and $20 \mu \mathrm{l}$ of Proteinase $\mathrm{K}$. The mixture was incubated overnight at $55^{\circ} \mathrm{C}$, thus, the tissues could be fully cleaved. The next day, $200 \mu \mathrm{l}$ of sample lysis buffer B was added to and incubated with them for $10 \mathrm{~min}$ at $70^{\circ} \mathrm{C}$. The sample was fully mixed with $200 \mu 1$ of dehydrated ethanol and then added to a clean spun column. The mixture was washed and centrifuged with a series of washing buffer. Finally, $50 \mu 1$ of elution buffer was pipetted into the spun column. The DNA was collected with the last high-speed centrifugation, and its concentration was adjusted to $80 \mathrm{ng} / \mu \mathrm{l}$ for the following analysis. The extracted DNA was amplified with Helicobacter genus-specific 16S rRNA primers (35): sense primer, 5'-GCT ATG ACG GGT ATC C-3' (C97F) and antisense primer, 5'-GAT TTT ACC CCT ACA CCA-3' (C98R). The sense and antisense primers amplified a 400 -bp product. We mixed $2 \mu \mathrm{l}$ of $80 \mathrm{ng} / \mu \mathrm{l}$ extracted DNA, $1 \mu \mathrm{l}$ of 20 pmol from each primer, $12.5 \mu \mathrm{l}$ of $2 \mathrm{X}$ Power Taq PCR MasterMix (Bioteke Corp., Beijing, China), and $8.5 \mu \mathrm{l}$ of sterilized ultrapure water. The mixture was amplified after a PCR cycle: initial denaturation with a Taq polymerase at $95^{\circ} \mathrm{C}$ for $10 \mathrm{~min}$, denaturation at $95^{\circ} \mathrm{C}$ for $30 \mathrm{sec}$, annealing at $55^{\circ} \mathrm{C}$ for $30 \mathrm{sec}$, extension at $75^{\circ} \mathrm{C}$ for $30 \mathrm{sec}$ ( 35 cycles), and a final extension step at $75^{\circ} \mathrm{C}$ for $5 \mathrm{~min}$. The amplified products were loaded onto $1.5 \%$ (weight/volume) agarose (Solarbio Technology Co., Ltd., Beijing, China) gels containing $0.04 \%$ (volume/volume) GoodView (Beijing SBS Genetech Co., Ltd., Beijing, China), and the production size was compared with a 100-bp DNA marker ladder (Pregene Biotechnology Co., Ltd., Beijing, China). H.pylori type strain NCTC 11637 was used as a positive control, while sterilized ultrapure water was used as a negative control for each PCR cycle. Bands were visualized and photographed under UV light. The 16S rRNA positive samples were sequenced by Biosune Biotechnology Co., Ltd., (Beijing, China) and blasted with $H$. pylori type strain NCTC 11637.

Immunohistochemical staining and quantitative analysis. Tissue sections were deparaffinized in xylene and rehydrated through graded alcohols to water. Slides were antigen unmasked by maintaining in a citrate buffer $(10 \mathrm{mmol} / \mathrm{l}$; $\mathrm{pH}$ 6.0) at a subboiling temperature for $20 \mathrm{~min}$. The sections were cooled on a bench top for $30 \mathrm{~min}$ and washed with PBS (pH 7.4) three times for 5 min each. Hydrogen peroxide (3\%) was incubated with the slides for $10 \mathrm{~min}$ and washed away, so endogenous peroxidase activity would be ceased. Sections were then incubated with polyclonal rabbit anti-H. pylori antibody (1:50 diluted in PBS, Product no. B047101; Dako, Glostrup, Denmark), monoclonal mouse anti-PCNA antibody (1:200 diluted in PBS, Product no. sc-56; Santa Cruz Biotechnology, Dallas, TX, USA), monoclonal mouse anti-Bcl-2 antibody (1:50 diluted in PBS, Product no. sc-7382; Santa Cruz Biotechnology), or polyclonal rabbit anti-Bax antibody (1:50 diluted in PBS, Product no. sc-526; Santa Cruz Biotechnology) overnight at $4^{\circ} \mathrm{C}$. The next day, we removed the primary antibody and washed the sections. A prepared rabbit or mouse SP kit (ZSGB-BIO, Beijing, China) was used according to the manufacturer's instructions, and we incubated the sections with solution A for $30 \mathrm{~min}$ and then with solution $\mathrm{B}$ for $45 \mathrm{~min}$ at $37^{\circ} \mathrm{C}$. We removed the reagents and washed them. DAB (ZSGB-BIO) was added to each section and the staining closely monitored. As soon as the sections had developed, they were immersed in PBS and counterstained in hematoxylin. Finally, the sections were dehydrated with graded alcohols to form xylene before mounting. The tissue sections must not dry out during the whole immunocytochemical staining procedure. Brown granules which were observed in the gastric lumens, hepatic sinusoid, cytoplasm, or nucleus were regarded as positive staining. The slides were observed under a light microscope (Olympus Corp., Tokyo, Japan), and five photographs of each section were randomly obtained at x40 magnification using the same conditions (light source, color saturation, brightness, gain and contrast). Photograph quantification was performed using Image-Pro Plus software, version 6.0 (Media Cybernetics, Inc., Silver Spring, MD, USA). In each field, the integrated optical density (IOD) for all positive staining was measured.

Protein extraction and western blotting. Twenty milligrams of the liver or tumor was completely triturated with an electric grinder, and the homogenate was mixed with $250 \mu \mathrm{l}$ of cold RIPA lysis buffer (Beyotime Institute of Biotechnology, Shanghai, China) containing $1 \mathrm{mM}$ of phenylmethylsulfonyl fluoride (PMSF). The mixture was centrifuged $(14,000 \mathrm{x} \mathrm{g}$, $4^{\circ} \mathrm{C}$ for $5 \mathrm{~min}$ ), and the supernatant was collected. The protein concentrations were detected using a BCA kit (Beyotime Institute of Biotechnology). The proteins (50-100 $\mu \mathrm{g} /$ lane) were electrophoresed in a $12 \%$ SDS-polyacrylamide gel and then transferred onto a PVDF membrane (Millipore Corp., Bedford, MA, USA). The membranes were blocked with 5\% skim milk in TBST at room temperature for $1 \mathrm{~h}$ and subsequently incubated overnight at $4^{\circ} \mathrm{C}$ with a primary antibody (PCNA at 1:500, Product no. sc-56; Bax at 1:500, Product no. sc-526; and Bcl-2 at 1:500, Product no. sc-7382). The next day, the membranes were incubated for $1 \mathrm{~h}$ at room temperature with a horseradish peroxidase-conjugated goat anti-rabbit or goat anti-mouse IgG secondary antibody (Zhongshan Golden Bridge Biotechnology Co., Ltd., Beijing, China) at 1:5,000. Finally, the protein bands on the membranes were detected using an ECL kit (Beyotime Institute of Biotechnology) and scanned with the ImageQuant LAS 4000 digital imaging system (GE Healthcare, Buckinghamshire, UK) or exposed to a medical radiography film (Kodak, Tokyo, Japan). The bands were quantified by Image-Pro Plus software. The IOD of each band was measured and expressed as mean \pm standard deviation (mean $\pm \mathrm{SD})$.

Statistical analysis. Measurement data are presented as mean \pm SD for normal data and median with ranges for nonnormal data, while enumeration data are presented as ratios. The data were analyzed using one-way ANOVA if they corresponded with both a normal distribution and homoscedasticity. The SPSS program package (version 11.0; SPSS, Inc., Chicago, IL, USA) was used for our statistical analysis. Differences were considered significant at P-value $<0.05$.

\section{Results}

Morphological, serologic and ascitic features of mice. The skin ulceration (Fig. 1) was observed in $27.8 \%$ (5/18) and $30 \%$ $(6 / 20)$ of mice in group A1 and B1, respectively. However, 

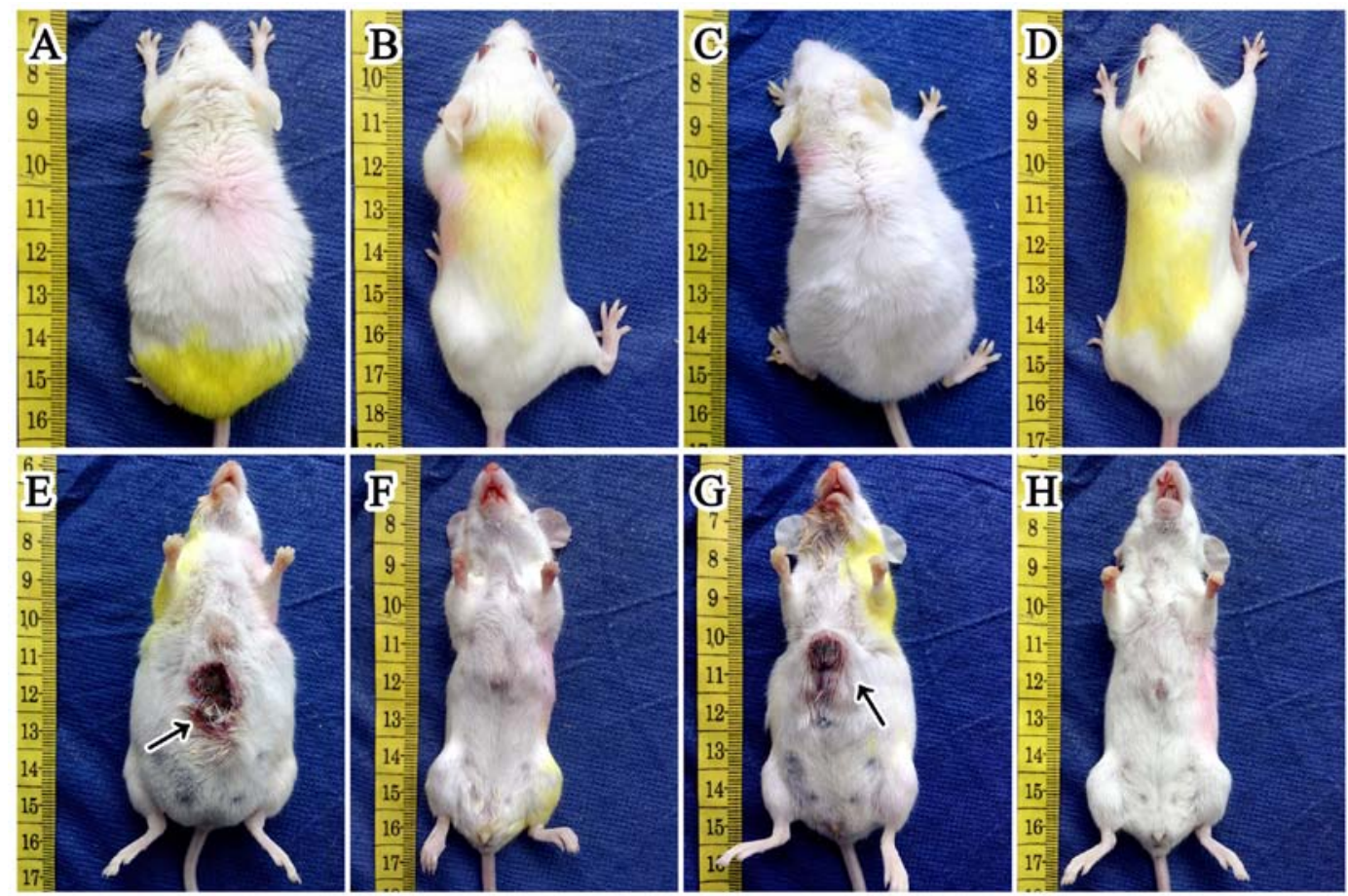

Figure 1. The differences among the mice. (A-D are dorsal views of the mice, and E-H are ventral views of the mice). The weight of the tumor positive mice (group A1 and B1) increased. Their abdomens bulged and representative ulcerations (arrows, 27.8\% in A1 and 30\% in B1) could be seen on the surface. Moreover, 50\% (9/18) and 45\% (9/20) of mice in group A1 and B1 had developed a large volume of hemorrhagic ascites. However, the appearance of the tumor negative mice (group A2 and B2) was normal, and no ulceration was visible on their abdomens. (A and E) H.pylori-infected and tumor positive mice (group A1); (B and F) H. pylori-infected and tumor negative mice (group A2); (C and G) uninfected and tumor positive mice (group B1); (D and H) uninfected and tumor negative mice (group B2). The mouse in each column represents two randomly selected individuals in each group.

there was no significant $(\mathrm{P}=0.583)$ difference between the two groups. We were unable to collect the skin ulceration for morphological detection. But we analyzed the 'link tissue' which connected hepatic tumor to abdominal wall instead of ulceration by H\&E stain. Consequently, we were not surprised at finding that it was full of tumor cells which were characteristic of cellular pleomorphism. Additionally, 50\% (9/18) and $45 \%$ (9/20) of mice in group A1 and B1 had developed ascites before they were necropsied. Moreover, $H$. pylori could not be cultured from any blood and ascites samples. AFP level (mean $\pm \mathrm{SD}, \mathrm{ng} / \mathrm{ml}$ ) of each group was $11.11 \pm 0.69$ (ascites of A1 group), $10.89 \pm 0.70$ (serum of A1 group), $10.99 \pm 0.67$ (serum of A2 group), $10.98 \pm 0.72$ (ascites of B1 group), 10.88 \pm 0.54 (serum of $\mathrm{B} 1$ group) and $11.08 \pm 0.71$ (serum of $\mathrm{B} 2$ group), respectively. However, no significant difference $(\mathrm{P}=0.962)$ could be found between any of the two groups above. Moreover, Helicobacter genus-specific 16S rRNA was not detected in blood or ascites samples.

Gastric H.pylori determination and histopathological assessment. H. pylori was cultured from gastric homogenate from 90\% (18 of 20) of the mice in group A1 (H. pylori infected and tumor positive mice) and $80 \%$ (16 of 20 ) of the mice in group A2 ( $H$. pylori infected and tumor negative mice). Helicobacter genus-specific 16S rRNA (Fig. 2) was detected using DNA extracted from the stomach, and a 95\% (19 of 20) positive rate was found in both group $A 1$ and $A 2$. Three to five positive PCR products in each group were randomly selected and sequenced. All the sequenced samples were completely homologous to $H$. pylori type strain NCTC 11637 .
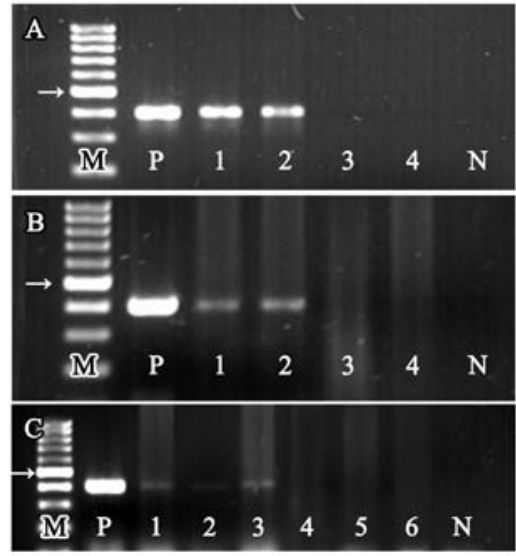

Figure 2. The PCR products of the Helicobacter genus-specific 16S rRNA from DNA of different mouse tissue samples, the size of all product was 400 bp. Lane 'M' represents 100 bp DNA marker ladder, and lanes 'P' and ' $\mathrm{N}$ ' represent positive control and negative control, respectively. The arrows, $500 \mathrm{bp}$ location of the marker. (A) 16S rRNA PCR products detected from bacterial colonies which were cultured from gastric suspensions. Lanes 1 and 2 represent the DNA samples extracted from bacterial colonies cultured from $H$. pylori-infected stomach (group A1 and A2), and lanes 3 and 4 represent the DNA samples extracted from bacterial colonies cultured from uninfected stomach (group B1 and B2). (B) 16S rRNA PCR products detected from gastric samples. Lanes 1 and 2, H. pylori-infected gastric DNA samples (group A1 and A2), and lanes 3 and 4, the uninfected gastric DNA samples (group B1 and B2). (C) 16S rRNA PCR products detected from liver and tumor samples. Lanes 1 and 2, liver and tumor DNA samples extracted from $H$. pylori-infected and tumor positive mice (group A1). Lane 3, hepatic DNA samples extracted from $H$.pylori-infected and tumor negative mice (group A2). Lanes 4 and 5, liver and tumor DNA samples extracted from uninfected and tumor positive mice (group B1). Lane 6, hepatic DNA samples extracted from uninfected and tumor negative mice (group B2). 


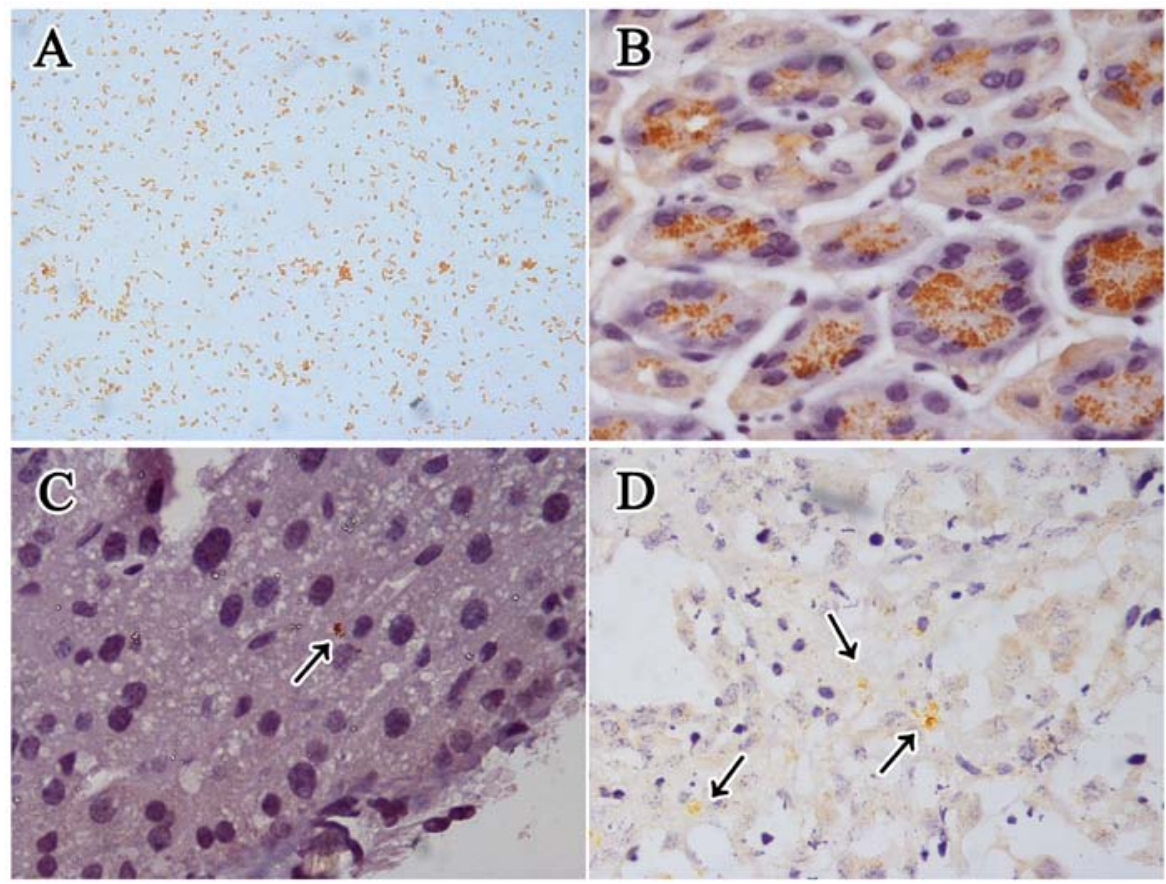

Figure 3. H. pylori was detected in the stomach, liver and tumor tissues using immunohistochemistry (IHC) staining (original magnification, $\mathrm{x} 1000$ ). (A) IHC staining of $H$.pylori type strain NCTC 11637. (B) Positive immunoreactivity was observed in the $H$. pylori-infected (group A1 and A2) gastric glands. (C) Positive immunoreactivity (arrows) was observed in some $H$. pylori-infected hepatic sinusoids (group A1 and A2). The heaptic samples were also positive for Helicobacter genus-specific 16S rRNA. (D) Immunopositive particles were observed in the necrotic area of tumors in the H.pylori-infected mice (group A1). The tumor samples were also positive for Helicobacter genus-specific 16S rRNA.
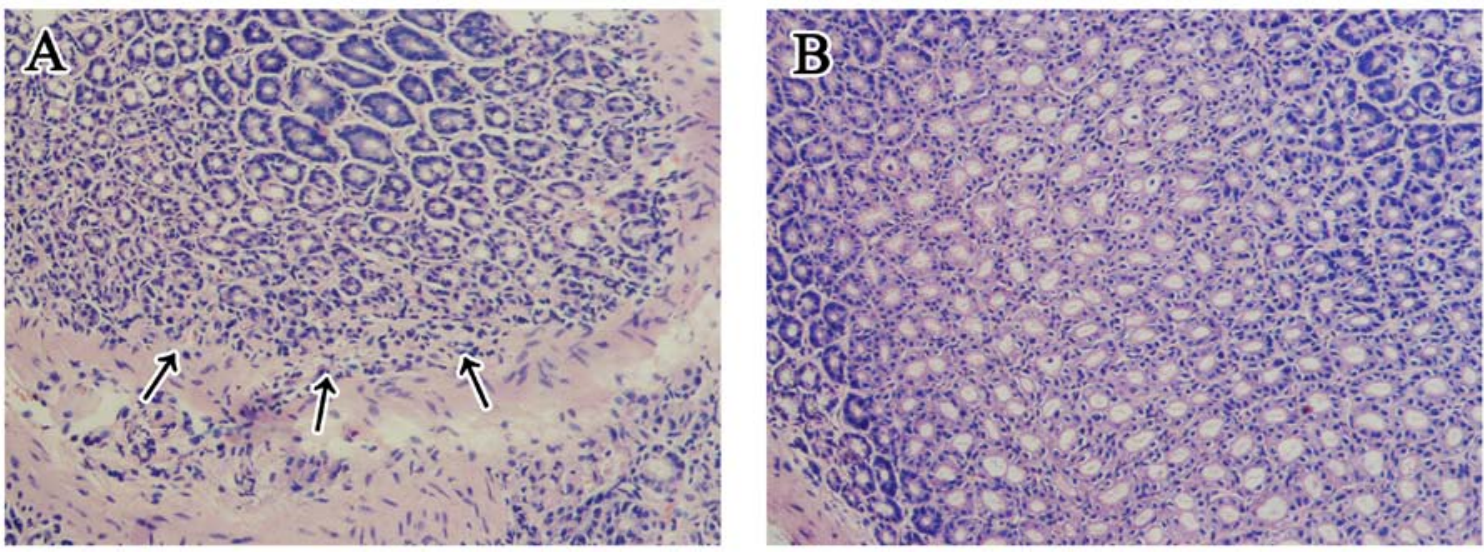

Figure 4. Histopathological changes in the mouse stomachs (both were stained using H\&E and magnified $\mathrm{x} 400$ ). (A) Histopathological changes in the H. pylori-infected gastric mucosa (group A1 and A2). The gastric glands in the basal layer were obscure, outlined and surrounded by chronic inflammatory cells (arrows); furthermore, the inflammatory changes were mild to moderate. (B) The uninfected gastric mucosa (group B1 and B2). Gastric glands were distinctly and sharply defined and outlined, while chronic inflammatory cells were not apparent.

IHC staining for H.pylori in Helicobacter genus-specific 16S rRNA positive gastric slides showed that it mainly colonized the gastric glands (Fig. 3). Although there was no apparent ulceration in any $H$. pylori-infected stomach (group A1 and A2), the histopathological changes (Fig. 4) indicated that chronic inflammatory cells infiltrated the pyloric antrum area, and the inflammatory changes were mild to moderate. All the pathogen detections above were negative for $H$. pylori in the uninfected stomachs (group B1 and B2), and chronic inflammatory cells were not apparent.

Detection of $H$. pylori in livers. The mice in group A1 $(\mathrm{n}=18)$ and A2 ( $n=16)$ whose gastric homogenates were positive for
H. pylori by culture method as well as all individuals in group $\mathrm{B} 1(\mathrm{n}=20)$ and B2 $(\mathrm{n}=10)$ were taken into the following detection and analysis procedures. H. pylori could not be cultured in any liver or tumor sample. The positive rate of Helicobacter genus-specific 16S rRNA (Fig. 2) for the liver and tumor samples in group A1 was $83.3 \%$ (15 of 18) and 66.7\% (12 of 18), respectively. The rate for the liver samples in group A2 was $87.5 \%$ (14 of 16). Three to five positive PCR products were also sequenced as previously described. All sequenced products were also completely homologous to $H$. pylori type strain NCTC 11637. H. pylori was mainly observed in the hepatic sinusoid and necrotic area of the tumors in the infected mice using IHC staining detection (Fig. 3), while none could 

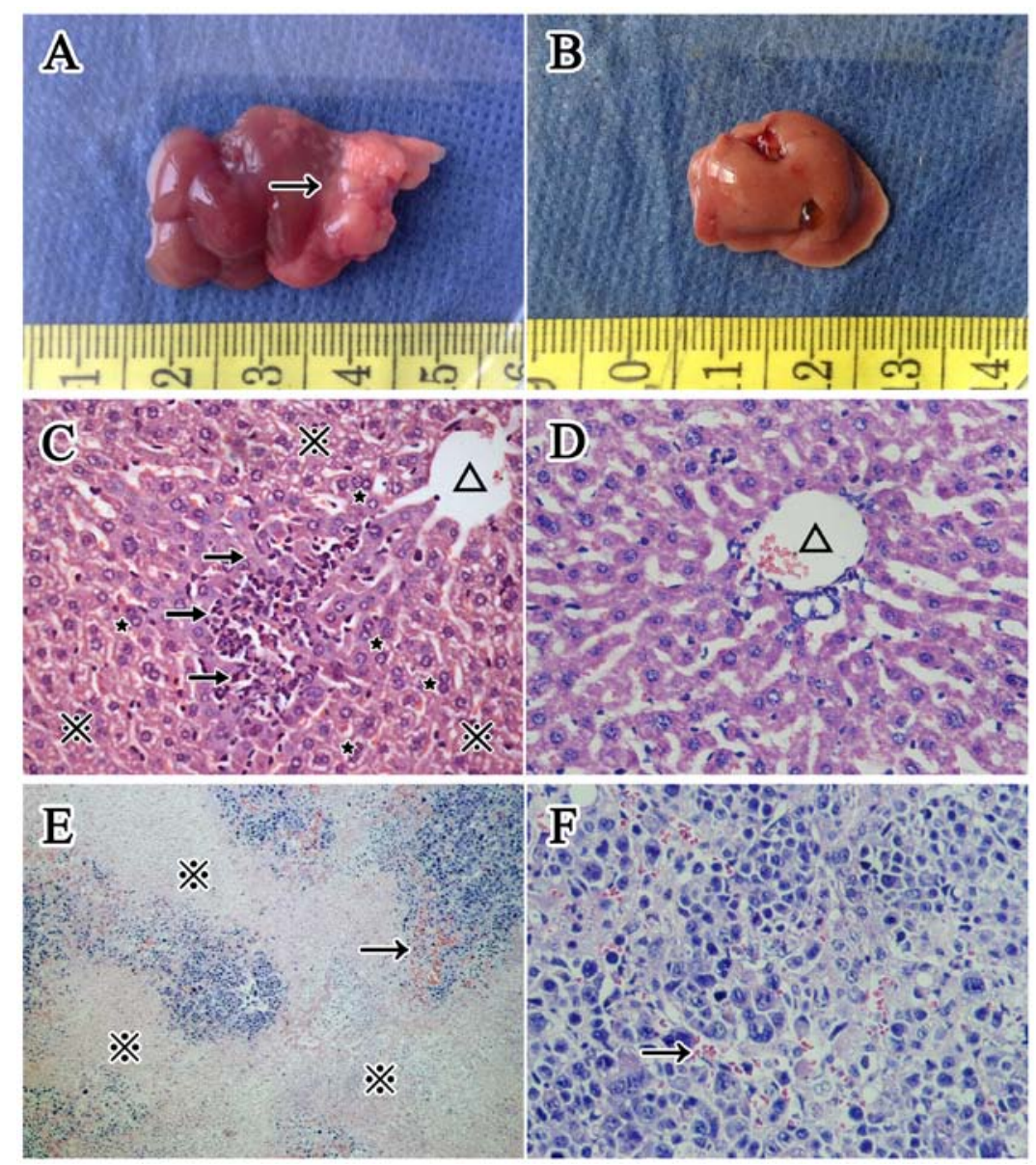

Figure 5. Morphological liver changes. (A) Carcinoma tissue (arrow) can be easily seen in the left liver lobe of the tumor positive mice (group A1 and B1). (B) No aberrant tissue can be observed in the hepatic gross specimen of the tumor negative mice (group A2 and B2). (C) Ballooning degeneration areas (※) and hepatic binucleate cells (asterisk) can be observed in the $\mathrm{H}$.pylori-infected liver (group A1 and A2), and the sinusoids were compressed by swollen hepatic cells. Moreover, thinly distributed inflammatory cells (arrows) were also observed in the liver. The triangle represents the central veins. H\&E stain (original magnification, x400). (D) Uninfected liver (group B1 and B2). Liver cell cords surround the central vein (triangle) radially, and sinusoids were distinctly and sharply outlined. Chronic inflammatory cells were not present. H\&E stain (original magnification, $\mathrm{x} 400)$. (E) The necrotic areas (※) of the tumors are homogeneously and lightly stained and distributed around the tumor parenchyma. Moreover, vasodilation (arrows) could be observed in the tumor cells H\&E stain (original magnification, x100. (F) Cellular pleomorphism and vasodilation (arrow) can be observed in the tumor parenchyma. H\&E stain (original magnification, $\mathrm{x} 400$ ).

be found in the tumor parenchyma. All the H.pylori detection methods were negative for the uninfected livers and tumors (group B1 and B2).

Morphological changes in the livers. We determined liver to body weight ratio for each group and show the average ratio (mean $\pm \mathrm{SD}$ ) of the mice in groups $\mathrm{A} 1, \mathrm{~A} 2, \mathrm{~B} 1$ and $\mathrm{B} 2$ was $0.072261 \pm 0.024696,0.045331 \pm 0.003885,0.062900 \pm 0.020324$, and $0.042018 \pm 0.004516$, respectively. The ratio of tumor positive mice (group A1 and B1) was significantly higher $(\mathrm{P}<0.001)$ than that of tumor negative mice (group A2 and B2), while there was no significant difference between $H$. pylori infected and uninfected mice, namely group $\mathrm{A} 1$ and $\mathrm{B} 1(\mathrm{P}=0.178)$ or group $\mathrm{A} 2$ and $\mathrm{B} 2(\mathrm{P}=0.635)$. Cytoplasmic vacuolation (ballooning degeneration) and hepatic binucleate cells could be observed in the H. pylori infected livers, and the sinusoids were compressed by swollen hepatic cells. In addition, the infiltrated inflammatory cells were thinly distributed in the hepatic lobules and also observed in the $H$. pylori infected livers. However, no visible microscopic difference existed between group A1 and B1 tumors. Both had characterized structural disorders and cellular pleomorphism such as atypia, increased nuclear-cytoplasmic ratio, hyperchromatic nuclei and pathological mitosis. Additionally, inflammatory cells and vasodilation could be observed among the tumor cells. The necrotic areas, which were homogeneous and lightly stained, were distributed around the tumor parenchyma (Figs. 1 and 5).

Protein expression in livers and tumors. We detected the expression of specific proteins in the livers and tumors by performing IHC staining and western blot analysis. Similar trends with IHC staining and western blot analysis were noted regarding PCNA and Bcl-2 expression. The PCNA expression (Figs. 6 and 7 and Table II) was significantly $(\mathrm{P} \leq 0.01)$ increased in the H.pylori infected tumors (group A1) as being compared with the uninfected tumors (group B1). Similarly, it was also significantly $(\mathrm{P}<0.05)$ increased in the $H$. pylori infected livers (group A1 and A2) as being compared with the uninfected livers (group B1 and B2). Additionally, the tumor PCNA expression (group A1 and B1) was dramatically increased $(\mathrm{P}<0.001)$ as compared with the liver (group A1, A2, B1 and 


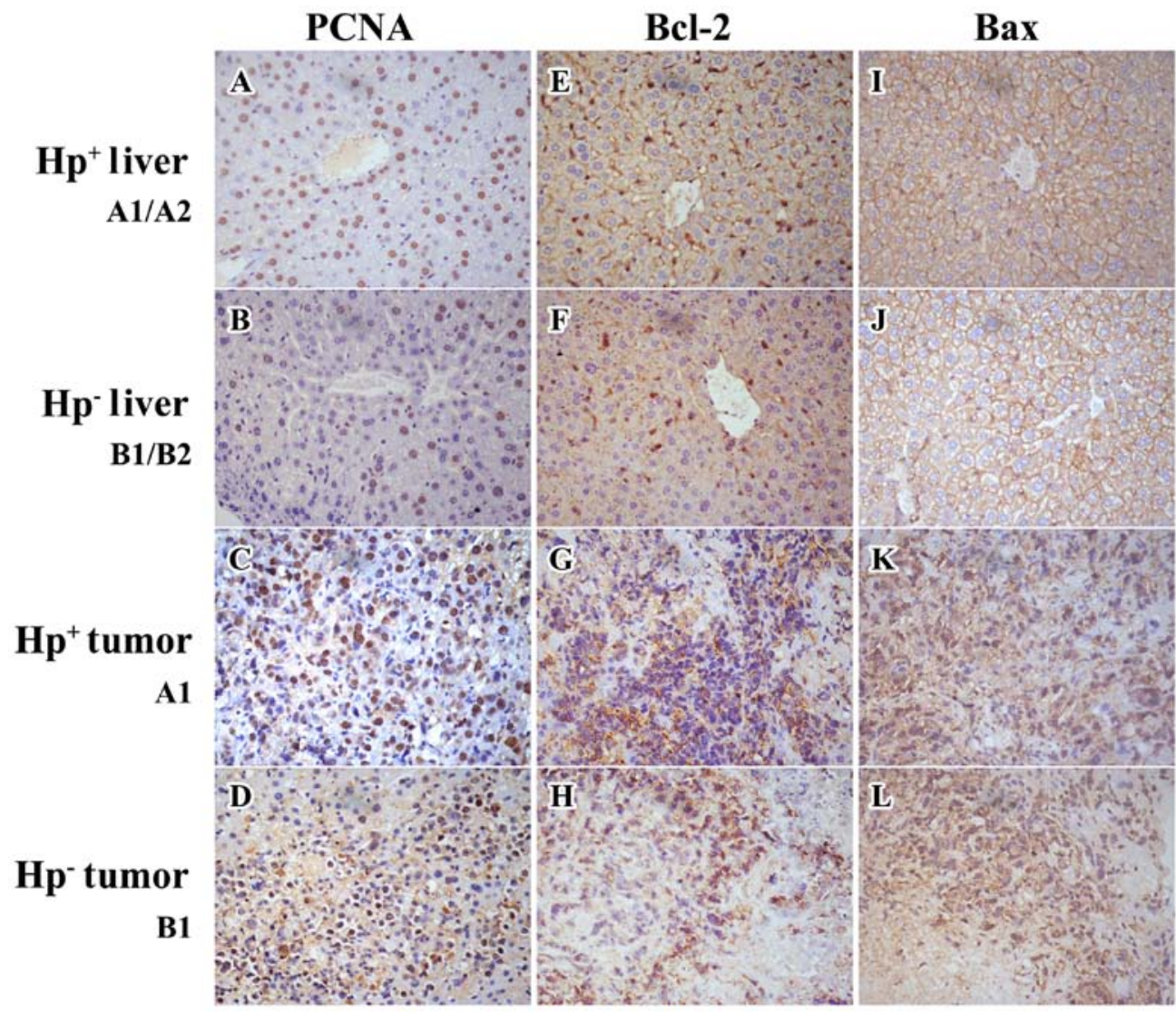

Figure 6. The (A-D) PCNA, (E-H) Bcl-2 and (I-L) Bax expression in the livers and tumors of representative sections. The integrated optical density (IOD) of the positive cells was assessed and expressed as mean $\pm \mathrm{SD}$ (Table II). IHC stain (original magnification, $\mathrm{x} 400$ ). (A, E and I) Liver tissues of $H$.pylori-infected mice (group A1 and A2). (B, F and J) Liver tissues of uninfected mice (group B1 and B2). (C, G and K) Tumor tissues of $H$. pylori-infected mice (group A1). (D, $\mathrm{H}$ and $\mathrm{L}$ ) Tumor tissues of uninfected mice (group B1).

$\mathbf{A}$

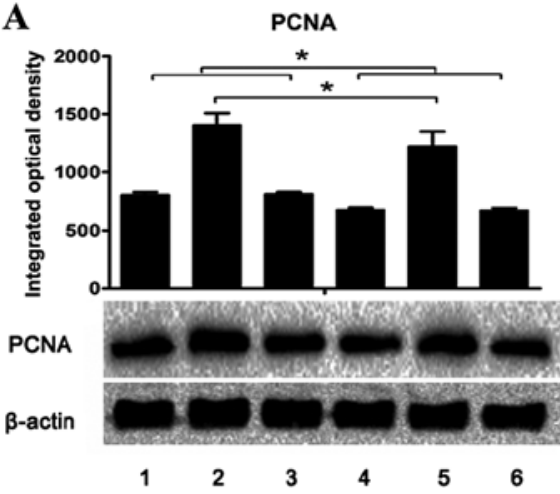

B

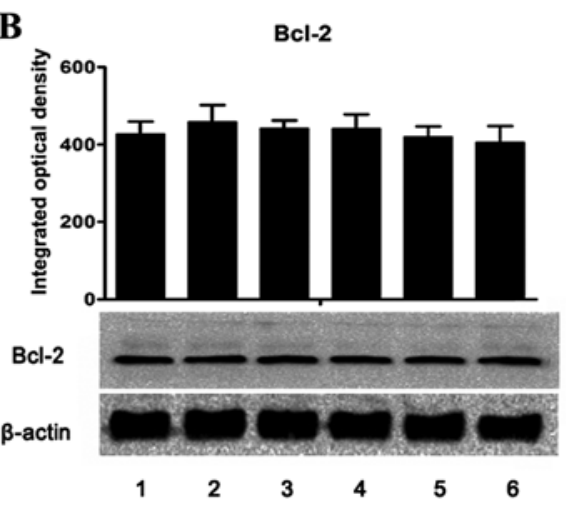

C

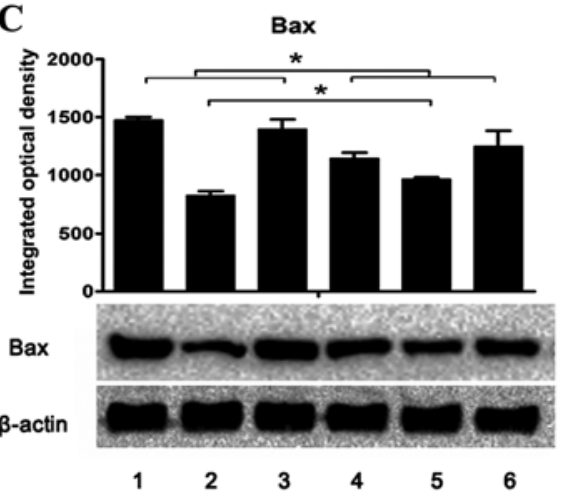

Figure 7. Expression of (A) PCNA, (B) Bcl-2 and (C) Bax in the livers and tumors was assessed using western blot analysis. The integrated optical density (IOD) of each antigen band was measured. The results are expressed as mean \pm SD in the histogram. Lanes 1 and 2 , the protein expression in the livers and tumors, respectively, of the $H$. pylori-infected and tumor positive mice (group A1). Lane 3, the protein expression in the livers of $H$. pylori-infected and tumor negative mice (group A2). Lanes 4 and 5, the protein expression in the livers and tumors, respectively, of the uninfected and tumor positive mice (group B1). Lane 6, the protein expression in the livers of uninfected and tumor negative mice (group B2). * $\mathrm{P}<0.05$ as lane 1 compared with lanes 4 or 6 , lane 3 compared with lanes 4 or 6 , and lane 2 compared with lane 5 .

B2). There was no difference $(\mathrm{P}>0.1)$ in the Bcl-2 expression (Figs. 6 and 7 and Table II) in any tumor or liver. With western blot analysis, a significant reduction $(\mathrm{P}=0.035)$ in the Bax expression (Fig. 7 and Table II) of the $H$.pylori-infected tumors was demonstrated (group A1) as compared with the uninfected tumors (group B1); there was no difference $(\mathrm{P}=0.176)$ in Bax expression (Fig. 6 and Table II) between these two groups with
IHC staining. However, both western blot analysis and IHC staining demonstrated a significant upregulation $(\mathrm{P}<0.05)$ of Bax expression in the H.pylori-infected livers (group A1 and A2), as compared with the uninfected livers (group B1 and B2). Moreover, the Bax expression in the tumors (group A1 and $\mathrm{B} 1)$ was significantly decreased $(\mathrm{P}<0.001)$, as compared with the livers (group A1, A2, B1 and B2). 
Table II. Integrated optical density of the proteins expressed in representative liver or tumor samples detected by immunohistochemical stain and western blot analysis (mean $\pm \mathrm{SD}$ ).

\begin{tabular}{|c|c|c|c|c|c|c|c|}
\hline \multirow[b]{2}{*}{ Group } & \multirow[b]{2}{*}{ Sample } & \multicolumn{2}{|c|}{ PCNA } & \multicolumn{2}{|c|}{$\mathrm{Bcl}-2$} & \multicolumn{2}{|c|}{$\operatorname{Bax}$} \\
\hline & & IHC & WB & IHC & WB & IHC & WB \\
\hline A1 & Liver & $660.384 \pm 24.196^{\mathrm{a}, \mathrm{b}}$ & $804.811 \pm 21.937^{\mathrm{a}, \mathrm{b}}$ & $257.009 \pm 25.241$ & $426.883 \pm 31.775$ & $568.872 \pm 35.024^{\mathrm{a}, \mathrm{b}}$ & $1473.967 \pm 25.356^{\mathrm{a}, \mathrm{b}}$ \\
\hline A1 & Tumor & $769.849 \pm 16.381^{c}$ & $1406.576 \pm 100.647^{c}$ & $284.988 \pm 12.188$ & $458.303 \pm 43.060$ & $309.306 \pm 20.036$ & $822.853 \pm 38.193^{c}$ \\
\hline A 2 & Liver & $657.051 \pm 13.166^{\mathrm{a}, \mathrm{b}}$ & $812.288 \pm 15.339^{\mathrm{a}, \mathrm{b}}$ & $243.345 \pm 25.150$ & $441.563 \pm 20.182$ & $533.919 \pm 15.386^{\mathrm{a}, \mathrm{b}}$ & $1395.167 \pm 85.053^{\mathrm{a}, \mathrm{b}}$ \\
\hline B1 & Liver & $452.964 \pm 15.665$ & $677.803 \pm 17.419$ & $283.233 \pm 38.032$ & $440.803 \pm 36.415$ & $449.545 \pm 30.011$ & $1145.367 \pm 50.639$ \\
\hline B1 & Tumor & $725.417 \pm 17.978$ & $1226.722 \pm 124.089$ & $275.016 \pm 21.806$ & $419.970 \pm 26.492$ & $336.763 \pm 15.308$ & $961.160 \pm 18.509$ \\
\hline $\mathrm{B} 2$ & Liver & $442.964 \pm 18.235$ & $672.141 \pm 18.418$ & $262.746 \pm 40.646$ & $405.830 \pm 41.563$ & $481.272 \pm 16.762$ & $1248.333 \pm 134.814$ \\
\hline
\end{tabular}

IHC, immunohistochemical stain. WB, western blotting. Results are shown with the mean $\pm \mathrm{SD}$. ${ }^{\mathrm{a}} \mathrm{P}<0.05$ (vs. $\mathrm{B} 1$ liver); ${ }^{\text {b }}<0.05$ (vs. $\mathrm{B} 2$ liver); ${ }^{\mathrm{c}} \mathrm{P}<0.05$ (vs. B1 tumor).

\section{Discussion}

H.pylori has been classified as a type I carcinogen (2), that is a major causative factor in many gastric diseases. Furthermore, some extragastric diseases are also correlated with its preinfection during childhood (4-7). Recent studies on the correlation between $H$. pylori infection and chronic hepatic disease have found that the anti-H. pylori antibody level in the serum of patients with chronic liver disease is significantly higher than that of healthy patients (8-12,36-40). In addition, $H$. pylori was also detected and confirmed in many liver samples from chronic hepatic disease patients using morphological and genetic detection $(8,13,14,24,41-43)$. Moreover, researchers have successfully cultured $H$. pylori from the liver samples of some clinical hepatic disease cases $(14,44)$. All the above mentioned details suggest that $H$. pylori could infect the human liver and may play a role in the development or progression of hepatic disease.

However, when talking about the role of $H$. pylori in the progression of hepatic diseases, there is no consistent opinion among researchers. Some investigator, such as Fox et al (35), Matsukura et al (45) and García et al (46) claimed that it could not colonize livers and was barely able to promote hepatic diseases. They rather regard it as contaminant instead of infection. However, others, such as Goo et al (23), Ito et al (24) and Rocha et al (47), reported that $H$. pylori not only colonize the livers, but also contribute to the hepatic disease evolution. Nowadays, investigators are gradually discovering a growing kinds of Helicobacter spp., such as $H$. bilis, H. pullorum and H. pylori, which has been found in the liver of hepatic disease patients. However, attention is mainly focused on $H$. bilis or $H$. pullorum $(35,45,46)$ rather than $H$. pylor $i$ for the following reasons. It has been confirmed by in vitro study that $H$. pylori was unable to survive in bile products (48). Moreover, cholecystectomy would increase the gastric Helicobacter infection risk (49). Relying on the crucial findings that $H$. pylori was unable to survive in hepatobiliary condition, the presence of $H$. pylori was considered a result of contamination rather than colonization, even though it had ever been found in gallbladder and bile of patients (50). In humans, bile is produced continuously by the hepatocytes (liver bile), but stored and concentrated in the gallbladder (gallbladder bile) (51). Ito et al (25), Zhang et al (26) and Chen et al (27) found $H$. pylori exhibited hepatotoxicity while it was co-cultured with hepatocytes which were capable of producing bile in vitro. Hence, they insisted $H$. pylori might play a potential role in hepatocarcinogenesis. Additionally, Goo et al (23), Ito et al (24) and Rocha et al (47) found all liver samples were negative for other gut organisms, such as E. coli, which mainly inhabited gut and more likely present in liver than $H$. pylori as a contaminant. Moreover, the successful $H$. pylori-cultivation from livers of patients $(14,44)$ also suggest its colonization rather than contamination. Finally, basing on the finding that $H$. pylori could be recovered from feces, Kelly et al (52) and Thomas et al (53) agreed with the opinion that it would survived even after exposure to bile. We came to the same conclusion as that summarized by Ito et al (25), Zhang et al (26) and Chen et al (27). However, bile products might transform $H$. pylori from virulent helical form to insufficient coccoid form (54). The colonization and pathology ability of $H$. pylori in liver may depend on its virulence factors, such as CagA or VacA $(25,55-57)$ and forms. Therefore, we thought the reasons for low $H$. pylori frequency in the study of Fox et al (35) may due to the insufficient strain or form of $H$. pylori which the researchers had adopted.

By using morphological (IHC staining) and genetic detection (PCR), the present study confirmed that H.pylori or only its structural components were both detected in stomachs and livers. It was mainly detected in the hepatic sinusoids and necrotic areas of the tumors. Currently, the following possible perspectives or hypotheses are widely accepted regarding the presence of $H$. pylori in the liver. Firstly, because its genetic components had been detected in cholecystic samples or the bile of gallbladder disease patients, some researchers consider the findings related to duodenal reflux (58-62). Gastrointestinal motility will transport $H$. pylori from the stomach to the descending duodenum. It would be gradually transmitted in a retrograde manner through the major duodenal papilla, sphincter of Oddi, common bile duct, common hepatic duct, left and right hepatic ducts, and cholangiole to its final destination in the liver or gallbladder. 
Secondly, the genetic components of $H$. pylori were detectable in the endarterium samples of atherosclerotic patients using PCR detection by Danesh et al (7) and others who indicated that $H$. pylori might enter into the circulatory system $(5,6,63)$. A long-term chronic $H$. pylori infection would result in chronic gastritis and a chronic gastric ulcer. Consequently, a small amount of $H$. pylori would constantly leak into the blood through impaired vessels that are in or around gastric ulcers and then wander aimlessly along the portal or lymph circulation. Tian et al (66) found that inflammatory cells were mostly thinly distributed along the central veins, hepatic sinusoids, arteriolar, and venules in the periportal area of H. pylori-infected livers. Although similar morphological changes were found in $H$. pylori-infected mouse livers of the present study, we could not detect $H$. pylori genus-specific $16 \mathrm{~S}$ rRNA in any of the blood samples. The low bacteria concentration $\left(<10^{3} \mathrm{CFU} / \mu \mathrm{l}\right)$ in the blood may be responsible for the negative results (60). Thus, even though it was undetectable in the blood of hepatic positive individuals, we cannot deny the abovementioned secondary hypothesis. Thirdly, inflammatory cells would phagocytize $H$. pylori and arrive at liver when the hepatic homeostatic equilibrium had been broken, for example, an increasing of bile $\mathrm{pH}$ value.

With a growing concern regarding the correlativity of $H$. pylori infection and hepatic disease, the positivity rate of $H$. pylori genetic components detected in hepatic samples is increasing. Although it is not uncommon for $H$. pylori to be cultured from the gastric samples of infected patients and animals, a positive culture from hepatic samples is still rarely reported. It has been reported that $H$. pylori could be cultured from clinical hepatic samples $(14,44)$. However, no positive culture result could be found in hepatic or blood samples of $H$. pylori-infected animal models which were developed by various researchers, including ourselves. By referring to the findings of researchers in the field, we analyzed the results and summarized the possible reasons as follows. First, by analyzing the results of $H$. pylori-specific IHC staining, we found that the densities of a positive reaction in $H$.pylori-infected livers were significantly lower than those of the stomachs. Silva et al (60) indicated the reasons why they were unable to visualize the $H$. pylori colonies stating that the bacteria were cultured in the conventional conditions and methods. Hence, a low detection sensitivity of bacterial culture may produce a false-negative result. H. pylori prefers gaseous conditions (2-5\% of oxygen and $5-10 \%$ of carbon dioxide), certain temperatures (34 to $40{ }^{\circ} \mathrm{C} ; 37^{\circ} \mathrm{C}$ is its optimum), humidity ( $\left.>90 \%\right)$, and acidity (pH 5.5 to 8.0 ; neutral is the optimum). H. pylori transforms from its normal form to a coccoid form if its growing environment changes (54), such as cholestasis in which hepatic cells excrete abnormal acidic bile. The coccoid form of $H$. pylori is widely known as a degenerative dead form or a nonculturable form $(64,65)$. In addition to its alkalinity, bile may also contain some other unfavorable ingredients that are unsuitable for the growth of $H$.pylori and would play a crucial role in restraining or killing it. Because the genetic components or structural proteins would not be eliminated completely by inflammatory or hepatic cells. Thus, we were able to realize the existence of $H$. pylori in samples by a more sensitive method, such as morphological IHC stain and PCR. Narikawa et al (54) also hypothesized that the coccoid transformation of $H$. pylori would contribute to the inability of $H$.pylori culture in hepatic samples despite a positive genetic detection.

Although, the liver to body weight ratio in $H$. pyloriinfected livers was not significant as compared with uninfected livers, cytoplasmic vacuolation and hepatic binucleate cells were observed by Goo et al (23), and the present study. In addition, infiltrated inflammatory cells that were thinly distributed in the $H$. pylori-infected hepatic lobules were also found by Tian et al (66). No macroscopic or microscopic differences existed in the $H$. pylori-infected and uninfected tumors, except for the pathogenic detection of $H$. pylori. In the present study, the skin ulceration bearing mouse usually bore an extremely gross exophytic growing hepatic tumor which stuck to the abdominal wall. We did not have the resources for skin ulceration detection, we analyzed the 'link tissue' instead and found that it was full of pleomorphic tumor cells. On that account, we insist that the skin ulceration was a part of the necrotic tumor, which had invaded into the abdominal wall. In order to explore the impact of $H$. pylori in the development and progression of liver and hepatic orthotopic graft tumors, we introduced three tumor markers, namely PCNA, Bax and Bcl-2, which are cellular growth, apoptosis-promotion and apoptosis-inhibition proteins, respectively. In the present study, H.pylori may have upregulated the expression of PCNA both in tumor and liver, whereas may have downregulated the Bax expression in the tumor and upregulated it in the liver. No significant impact of $H$. pylori on the Bcl-2 expression could be seen in the tumor or the liver.

PCNA was a 36-kDa antigen which was associated with cellular growth activity (67-70). It plays an important role in cellular proliferation and DNA synthesis, and its expression is usually proportional to DNA synthesis. Hence, it is widely thought to be an indicator and is used to estimate the occurrence, development, metastasis, progression, classification, neoplasm staging, treatment evaluation and prognosis of many tumors (71-74). In actively proliferative cells, such as tumor cells, the expression of PCNA is significantly upregulated (75-80). In the present study, besides the significantly unregulated expression in tumors, PCNA in H. pyloriinfected livers and tumors was also markedly higher than that in the uninfected ones. Our results corresponded to the findings of Goo et al (23) and Tian et al (81). We noted that the swollen cells in the $H$. pylori-infected livers compressed the hepatic sinusoids, and subsequently, might lead to the blood and oxygen deficits. The impaired hepatic cells might induce the expression of PCNA indirectly as the deficits in nutrition, oxygen and blood supply. Moreover, inflammatory cells and their infection factors might contribute to PCNA upregulation in hepatic cells. This is our hypothesis for the reasons for PCNA upregulation that was detected in $H$. pylori-infected livers. Moreover, Tian et al (81) performed an in vitro experiment involving the human liver HepG2 cells and $H$. pylori co-culture indicating an increasing PCNA expression. However, the liver cells in their study were in an abundant nutritious, oxygen and blood condition (82). Thus, we infer from the results that $H$. pylori may promote cellular proliferation in some direct but unknown pathways.

The Bcl-2 family is divided into two categories. One is a type of regulator protein that induces cell apoptosis, such as Bax. The other, especially Bcl-2, is considered an impor- 
tant anti-apoptosis protein. The Bcl-2 family antigen would combine with each other and become a protein dimer which act as a molecular switch in the progression of cell death (83-88). The occurrence of carcinoma is an imbalance between cellular growth or proliferation and cellular death or apoptosis. The upregulation of proto-oncogenes or downregulation of anti-oncogenes would finally promote tumor progression. When the Bax expression were higher than that of Bcl-2, they would combine as Bax/Bax homologous dimers and promote cellular apoptosis. Alternatively, the Bcl-2 and Bax antigens would combine as Bcl-2/Bax heterodimers and Bcl-2/Bcl-2 homodimers and play a role in inhibiting cellular apoptosis (86,89-92). Deficits in nutrients, oxygen, and blood supply might be a crucial reason for cellular apoptosis in the present study (93). Additionally, inflammatory factors or mediators excreted by infiltrating inflammatory cells were also responsible for cellular apoptosis. All the above mentioned reasons enabled the cellular apoptosis in $H$.pylori-infected livers and led them to have a higher Bax expression. Hemangiectasis was noted in the tumors, thus, their blood and oxygen supply were abundant. Moreover, the percentage of death and apoptosis was significantly lower in the tumor than the normal liver tissue. Thus, we were able to explain the downregulation of the Bax expression demonstrated in the present study. We conclude from the results that inflammation might be the primary cause of apoptosis in the $H$. pylori-infected livers, but $H$. pylori might act as a crucial factor to inhibit or reduce tumorous apoptosis.

The present study has some shortcomings. We could not establish the H.pylori forms and the exact reasons for hepatic inflammation. Additionally, it is unknown whether the difference among groups will be more significantly visible when the model-build period is prolonged. Therefore, further research is essential for the worldwide unsolved issues that were found in exploring the relationship between $H$. pylori and hepatic diseases.

\section{Acknowledgements}

Our research was supported by the Provincial Natural Science Foundation of Fujian (code: 2012J01358) and by the Construction Project of National Key Clinical Subject of General Surgery.

\section{References}

1. Rybicka M, Nakonieczna J, Stalke P and Bielawski KP: Host response to the presence of Helicobacter spp. DNA in the liver of patients with chronic liver diseases. Pol J Microbiol 60: 175-178, 2011.

2. Schistosomes, liver flukes and Helicobacter pylori. IARC Working Group on the Evaluation of Carcinogenic Risks to Humans. Lyon, 7-14 June 1994. IARC monographs on the evaluation of carcinogenic risks to humans/World Health Organization, International Agency for Research on Cancer 61: 1-241, 1994.

3. Wedi B and Kapp A: Helicobacter pylori infection in skin diseases: a critical appraisal. Am J Clin Dermatol 3: 273-282, 2002.

4. Pellicano R, Menard A, Rizzetto M and Megraud F: Helicobacter species and liver diseases: association or causation? Lancet Infect Dis 8: 254-260, 2008

5. Farsak B, Yildirir A, Akyön Y, Pinar A, Oc M, Böke E, Kes S and Tokgözoğlu L: Detection of Chlamydia pneumoniae and Helicobacter pylori DNA in human atherosclerotic plaques by PCR. J Clin Microbiol 38: 4408-4411, 2000.
6. Ameriso SF, Fridman EA, Leiguarda RC and Sevlever GE: Detection of Helicobacter pylori in human carotid atherosclerotic plaques. Stroke 32: 385-391, 2001.

7. Danesh J, Koreth J, Youngman L, Collins R, Arnold JR, Balarajan Y, McGee J and Roskell D: Is Helicobacter pylori a factor in coronary atherosclerosis? J Clin Microbiol 37: 1651, 1999.

8. Nilsson I, Lindgren S, Eriksson S and Wadstrom T: Serum antibodies to Helicobacter hepaticus and Helicobacter pylori in patients with chronic liver disease. Gut 46: 410-414, 2000.

9. Pellicano R, Leone N, Berrutti M, Cutufia MA, Fiorentino M, Rizzetto $\mathrm{M}$ and Ponzetto A: Helicobacter pylori seroprevalence in hepatitis $\mathrm{C}$ virus positive patients with cirrhosis. J Hepatol 33: 648-650, 2000

10. Ponzetto A, Pellicano R, Leone N, Berrutti M, Turrini F and Rizzetto M: Helicobacter pylori seroprevalence in cirrhotic patients with hepatitis B virus infection. Neth J Med 56: 206-210, 2000.

11. Ponzetto A, Pellicano R, Leone N, Cutufia MA, Turrini F, Grigioni WF, D'Errico A, Mortimer P, Rizzetto M and Silengo L: Helicobacter infection and cirrhosis in hepatitis $\mathrm{C}$ virus carriage: is it an innocent bystander or a troublemaker? Med Hypotheses 54: $275-277,2000$

12. Queiroz DM, Rocha AM, Rocha GA, Cinque SM, Oliveira AG, Godoy A and Tanno H: Association between Helicobacter pylori infection and cirrhosis in patients with chronic hepatitis $\mathrm{C}$ virus. Dig Dis Sci 51: 370-373, 2006.

13. Avenaud P, Marais A, Monteiro L, Le Bail B, Bioulac Sage P, Balabaud C and Mégraud F: Detection of Helicobacter species in the liver of patients with and without primary liver carcinoma. Cancer 89: 1431-1439, 2000.

14. Xuan SY, Li N, Qiang X, Zhou RR, Shi YX and Jiang WJ: Helicobacter infection in hepatocellular carcinoma tissue. World J Gastroenterol 12: 2335-2340, 2006.

15. Farazi PA and DePinho RA: Hepatocellular carcinoma pathogenesis: from genes to environment. Nat Rev Cancer 6: 674-687, 2006.

16. Ferlay J, Soerjomataram I, Dikshit R, Eser S, Mathers C, Rebelo M, Parkin DM, Forman D and Bray F: Cancer incidence and mortality worldwide: sources, methods and major patterns in GLOBOCAN 2012. Int J Cancer 136: E359-E386, 2015.

17. Parkin DM, Bray F, Ferlay $J$ and Pisani P: Global cancer statistics, 2002. CA Cancer J Clin 55: 74-108, 2005.

18. Iwatsuki S, Starzl TE, Sheahan DG, Yokoyama I, Demetris AJ, Todo S, Tzakis AG, Van Thiel DH, Carr B, Selby R, et al: Hepatic resection versus transplantation for hepatocellular carcinoma. Ann Surg 214: 221-228; discussion 228-229, 1991.

19. McPeake JR, O'Grady JG, Zaman S, Portmann B, Wight DG, Tan KC, Calne RY and Williams R: Liver transplantation for primary hepatocellular carcinoma: tumor size and number determine outcome. J Hepatol 18: 226-234, 1993.

20. Kensler TW, Roebuck BD, Wogan GN and Groopman JD: Aflatoxin: a 50-year odyssey of mechanistic and translational toxicology. Toxicol Sci 120 (Suppl 1): S28-S48, 2011.

21. Chuang SC, La Vecchia C and Boffetta P: Liver cancer: Descriptive epidemiology and risk factors other than HBV and HCV infection. Cancer Lett 286: 9-14, 2009.

22. Arzumanyan A, Reis HM and Feitelson MA: Pathogenic mechanisms in HBV- and HCV-associated hepatocellular carcinoma. Nat Rev Cancer 13: 123-135, 2013.

23. Goo MJ, Ki MR, Lee HR, Yang HJ, Yuan DW, Hong IH, Park JK, Hong KS, Han JY, Hwang OK, et al: Helicobacter pylori promotes hepatic fibrosis in the animal model. Lab Invest 89: 1291-1303, 2009.

24. Ito K, Nakamura M, Toda G, Negishi M, Torii A and Ohno T: Potential role of Helicobacter pylori in hepatocarcinogenesis. Int J Mol Med 13: 221-227, 2004

25. Ito K, Yamaoka Y, Ota H, El-Zimaity H and Graham DY: Adherence, internalization, and persistence of Helicobacter pylori in hepatocytes. Dig Dis Sci 53: 2541-2549, 2008.

26. Zhang Y, Fan XG, Huang YK, Chen R and Dai H: Helicobacter pylori enhances cyclin D1, PCNA expression in HepG2 cell line. Zhonghua Gan Zang Bing Za Zhi 12: 695-696, 2004 (In Chinese)

27. Chen R, Fan XG, Huang Y, Li N and Chen CH: In vitro cytotoxicity of Helicobacter pylori on hepatocarcinoma HepG2 cells. Ai Zheng 23: 44-49, 2004 (In Chinese)

28. Karita M, Li Q, Cantero D and Okita K: Establishment of a small animal model for human Helicobacter pylori infection using germ-free mouse. Am J Gastroenterol 89: 208-213, 1994.

29. Thalmaier U, Lehn N, Pfeffer K, Stolte M, Vieth M and Schneider-Brachert W: Role of tumor necrosis factor alpha in Helicobacter pylori gastritis in tumor necrosis factor receptor 1-deficient mice. Infect Immun 70: 3149-3155, 2002. 
30. Algood HM, Allen SS, Washington MK, Peek RM Jr, Miller GG and Cover TL: Regulation of gastric B cell recruitment is dependent on IL-17 receptor A signaling in a model of chronic bacterial infection. J Immunol 183: 5837-5846, 2009.

31. Maurer KJ, Ihrig MM, Rogers AB, Ng V, Bouchard G, Leonard MR, Carey MC and Fox JG: Identification of cholelithogenic enterohepatic Helicobacter species and their role in murine cholesterol gallstone formation. Gastroenterology 128 : 1023-1033, 2005.

32. Lee CW, Rickman B, Rogers AB, Muthupalani S, Takaishi S, Yang P, Wang TC and Fox JG: Combination of sulindac and antimicrobial eradication of Helicobacter pylori prevents progression of gastric cancer in hypergastrinemic INS-GAS mice. Cancer Res 69: 8166-8174, 2009.

33. Yao X, Hu JF, Daniels M, Yien H, Lu H, Sharan H, Zhou X, Zeng Z, Li T, Yang Y, et al: A novel orthotopic tumor mode to study growth factors and oncogenes in hepatocarcinogenesis. Clin Cancer Res 9: 2719-2726, 2003.

34. Aprahamian M, Bour G, Akladios CY, Fylaktakidou K Greferath R, Soler L, Marescaux J, Egly JM, Lehn JM and Nicolau C: Myo-InositolTrisPyroPhosphate treatment leads to HIF-1 $\alpha$ suppression and eradication of early hepatoma tumors in rats. Chem Biochem 12: 777-783, 2011.

35. Fox JG, Dewhirst FE, Shen Z, Feng Y, Taylor NS, Paster BJ, Ericson RL, Lau CN, Correa P, Araya JC, et al: Hepatic Helicobacter species identified in bile and gallbladder tissue from Chileans with chronic cholecystitis. Gastroenterology 114: 755-763, 1998.

36. Leone N, Pellicano R, Brunello F, Cutufia MA, Berrutti M, Fagoonee S, Rizzetto M and Ponzetto A: Helicobacter pylori seroprevalence in patients with cirrhosis of the liver and hepatocellular carcinoma. Cancer Detect Prev 27: 494-497, 2003.

37. Ponzetto A, Pellicano R, Redaelli A, Rizzetto M and Roffi L: Helicobacter pylori infection in patients with hepatitis C Virus positive chronic liver diseases. New Microbiol 26: 321-328, 2003.

38. Spinzi G, Pellicano R, Minoli G, Terreni N, Cutufia MA Fagoonee S, Rizzetto M and Ponzetto A: Helicobacter pylori seroprevalence in hepatitis $\mathrm{C}$ virus positive patients with cirrhosis. The Como cross-sectional study. Panminerva Med 43: $85-87,2001$.

39. Fan XG, Zou YY, Wu AH, Li TG, Hu GL and Zhang Z: Seroprevalence of Helicobacter pylori infection in patients with hepatitis B. Br J Biomed Sci 55: 176-178, 1998.

40. Zhang S, Bao Y and Zu MH: Research of relationship between Hp infection and HCC. Chin J Clin Oncol 45-48, 2004.

41. Huang Y, Fan XG, Wang ZM, Zhou JH, Tian XF and Li N Identification of helicobacter species in human liver samples from patients with primary hepatocellular carcinoma. J Clin Pathol 57: 1273-1277, 2004

42. Pellicano R, Mazzaferro V, Grigioni WF, Cutufia MA, Fagoonee S, Silengo L, Rizzetto M and Ponzetto A: Helicobacter species sequences in liver samples from patients with and without hepatocellular carcinoma. World J Gastroenterol 10: 598-601, 2004.

43. Leelawat K, Suksumek N, Leelawat S and Lek-Uthai U: Detection of VacA gene specific for Helicobactor pylori in hepatocellular carcinoma and cholangiocarcinoma specimens of Thai patients. Southeast Asian J Trop Med Public Health 38 : 881-885, 2007

44. de Magalhaes Queiroz DM and Santos A: Isolation of a Helicobacter strain from the human liver. Gastroenterology 121 1023-1024, 2001

45. Matsukura N, Yokomuro S, Yamada S, Tajiri T, Sundo T, Hadama T, Kamiya S, Naito Z and Fox JG: Association between Helicobacter bilis in bile and biliary tract malignancies: $H$. bilis in bile from Japanese and Thai patients with benign and malignant diseases in the biliary tract. Jpn J Cancer Res 93 : 842-847, 2002

46. García A, Feng Y, Parry NM, McCabe A, Mobley MW, Lertpiriyapong K, Whary MT and Fox JG: Helicobacter pylori infection does not promote hepatocellular cancer in a transgenic mouse model of hepatitis $C$ virus pathogenesis. Gut Microbes 4 : 577-590, 2013

47. Rocha M, Avenaud P, Menard A, Le Bail B, Balabaud C, Bioulac-Sage P, de Magalhães Queiroz DM and and Mégraud F Association of Helicobacter species with hepatitis C cirrhosis with or without hepatocellular carcinoma. Gut 54: 396-401, 2005.

48. Hanninen ML: Sensitivity of Helicobacter pylori to different bile salts. Eur J Clin Microbiol Infect Disy 10: 515-518, 1991.
49. Caldwell MT, McDermott M, Jazrawi S, O'Dowd G, Byrne PJ, Walsh TN, Hourihane DO and Hennessy TP: Helicobacter pylori infection increases following cholecystectomy. Ir J Med Sci 164: 52-55, 1995

50. Kawaguchi M, Saito T, Ohno H, Midorikawa S, Sanji T, Handa Y, Morita S, Yoshida H, Tsurui M, Misaka R, et al: Bacteria closely resembling Helicobacter pylori detected immunohistologically and genetically in resected gallbladder mucosa. J Gastroenterol 31: 294-298, 1996

51. Guyton JE and Hall AC: Textbook of Medical Physiology. Saunders Elsevier, Philadelphia, PA, 2011

52. Kelly SM, Pitcher MC, Farmery SM and Gibson GR: Isolation of Helicobacter pylori from feces of patients with dyspepsia in the United Kingdom. Gastroenterology 107: 1671-1674, 1994.

53. Thomas JE, Gibson GR, Darboe MK, Dale A and Weaver LT: Isolation of Helicobacter pylori from human faeces. Lancet 340 : 1194-1195, 1992.

54. Narikawa S, Kawai S, Aoshima H, Kawamata O, Kawaguchi R, Hikiji K, Kato M, Iino S and Mizushima Y: Comparison of the nucleic acids of helical and coccoid forms of Helicobacter pylori. Clin Diagn Lab Immunol 4: 285-290, 1997.

55. Dore MP, Realdi G, Mura D, Graham DY and Sepulveda AR: Helicobacter infection in patients with $\mathrm{HCV}$-related chronic hepatitis, cirrhosis, and hepatocellular carcinoma. Dig Dis Sci 47: 1638-1643, 2002

56. Silva LD, Rocha AM, Rocha GA, de Moura SB, Rocha MM, Dani R, de Melo FF, Guerra JB, de Castro LP, Mendes GS, et al: The presence of Helicobacter pylori in the liver depends on the Th1, Th17 and Treg cytokine profile of the patient. Mem Inst Oswaldo Cruz 106: 748-754, 2011.

57. Boonyanugomol W, Chomvarin C, Sripa B, Bhudhisawasdi V, Khuntikeo N, Hahnvajanawong $\mathrm{C}$ and Chamsuwan A: Helicobacter pylori in Thai patients with cholangiocarcinoma and its association with biliary inflammation and proliferation. HPB (Oxford) 14: 177-184, 2012.

58. Myung SJ, Kim MH, Shim KN, Kim YS, Kim EO, Kim HJ, Park ET, Yoo KS, Lim BC, Seo DW, et al: Detection of Helicobacter pylori DNA in human biliary tree and its association with hepatolithiasis. Dig Dis Sci 45: 1405-1412, 2000.

59. Chen W, Li D, Cannan RJ and Stubbs RS: Common presence of Helicobacter DNA in the gallbladder of patients with gallstone diseases and controls. Dig Liver Dis 35: 237-243, 2003.

60. Silva CP, Pereira-Lima JC, Oliveira AG, Guerra JB, Marques DL, Sarmanho L, Cabral MM and Queiroz DM: Association of the presence of Helicobacter in gallbladder tissue with cholelithiasis and cholecystitis. J Clin Microbiol 41: 5615-5618, 2003.

61. Maurer KJ, Rogers AB, Ge Z, Wiese AJ, Carey MC and Fox JG: Helicobacter pylori and cholesterol gallstone formation in C57L/J mice: A prospective study. Am J Physiol Gastrointest Liver Physiol 290: G175-G182, 2006.

62. Abayli B, Colakoglu S, Serin M, Erdogan S, Isiksal YF, Tuncer I, Koksal F and Demiryurek H: Helicobacter pylori in the etiology of cholesterol gallstones. J Clin Gastroenterol 39: 134-137, 2005.

63. Kowalski M, Rees W, Konturek PC, Grove R, Scheffold T, Meixner H, Brunec M, Franz N, Konturek JW, Pieniazek P, et al: Detection of Helicobacter pylori specific DNA in human atheromatous coronary arteries and its association to prior myocardial infarction and unstable angina. Dig Liver Dis 34: 398-402, 2002

64. Kusters JG, Gerrits MM, Van Strijp JA and VandenbrouckeGrauls CM: Coccoid forms of Helicobacter pylori are the morphologic manifestation of cell death. Infect Immun 65: 3672-3679, 1997.

65. Andersen LP, Dorland A, Karacan H, Colding H, Nilsson HO, Wadström T and Blom J: Possible clinical importance of the transformation of Helicobacter pylori into coccoid forms. Scand J Gastroenterol 35: 897-903, 2000.

66. Tian XF, Fan XG, Fu CY, Huang Y and Zhu C: Experimental study on the pathological effect of Helicobacter pylori on liver tissues. Zhonghua Gan Zang Bing Za Zhi 13: 780-783, 2005 (In Chinese).

67. Egelkrout EM, Mariconti L, Settlage SB, Cella R, Robertson D and Hanley-Bowdoin L: Two E2F elements regulate the proliferating cell nuclear antigen promoter differently during leaf development. Plant Cell 14: 3225-3236, 2002.

68. Essers J, Theil AF, Baldeyron C, van Cappellen WA, Houtsmuller AB, Kanaar R and Vermeulen W: Nuclear dynamics of PCNA in DNA replication and repair. Mol Cell Biol 25: 9350-9359, 2005. 
69. Shivji KK, Kenny MK and Wood RD: Proliferating cell nuclear antigen is required for DNA excision repair. Cell 69: 367-374, 1992.

70. Leonardi E, Girlando S, Serio G, Mauri FA, Perrone G, Scampini S, Dalla Palma P and Barbareschi M: PCNA and Ki67 expression in breast carcinoma: correlations with clinical and biological variables. J Clin Pathol 45: 416-419, 1992.

71. Kobayashi I, Matsuo K, Ishibashi Y, Kanda S and Sakai H: The proliferative activity in dysplasia and carcinoma in situ of the uterine cervix analyzed by proliferating cell nuclear antigen immunostaining and silver-binding argyrophilic nucleolar organizer region staining. Hum Pathol 25: 198-202, 1994.

72. Allegranza A, Girlando S, Arrigoni GL, Veronese S, Mauri FA, Gambacorta M, Pollo B, Dalla Palma P and Barbareschi M: Proliferating cell nuclear antigen expression in central nervous system neoplasms. Virchows Arch A Pathol Anat Histopathol 419: 417-423, 1991.

73. Tsai ST and Jin YT: Proliferating cell nuclear antigen (PCNA) expression in oral squamous cell carcinomas. J Oral Pathol Med 24: 313-315, 1995.

74. Willett CG1, Warland G, Hagan MP, Daly WJ, Coen J, Shellito PC and Compton CC: Tumor proliferation in rectal cancer following preoperative irradiation. J Clin Oncol 13: 1417-1424, 1995.

75. Prosperi E: Multiple roles of the proliferating cell nuclear antigen: DNA replication, repair and cell cycle control. Prog Cell Cycle Res 3: 193-210, 1997.

76. Moldovan GL, Pfander B and Jentsch S: PCNA, the maestro of the replication fork. Cell 129: 665-679, 2007.

77. Wang SC, Nakajima Y, Yu YL, Xia W, Chen CT, Yang CC, McIntush EW, Li LY, Hawke DH, Kobayashi R and Hung MC: Tyrosine phosphorylation controls PCNA function through protein stability. Nat Cell Biol 8: 1359-1368, 2006.

78. Pal HC1, Sharma S, Strickland LR, Agarwal J, Athar M, Elmets CA and Afaq F: Delphinidin reduces cell proliferation and induces apoptosis of non-small-cell lung cancer cells by targeting EGFR/VEGFR2 signaling pathways. PLoS One 8: e77270, 2013

79. Aziz MH, Wheeler DL, Bhamb B and Verma AK: Protein kinase $\mathrm{C}$ delta overexpressing transgenic mice are resistant to chemically but not to UV radiation-induced development of squamous cell carcinomas: A possible link to specific cytokines and cyclooxygenase-2. Cancer Res 66: 713-722, 2006.

80. Ojeh N, Hiilesvuo K, Warri A, Salmivirta M, Henttinen T and Maatta A: Ectopic expression of syndecan-1 in basal epidermis affects keratinocyte proliferation and wound re-epithelialization. J Invest Dermatol 128: 26-34, 2008.
81. Tian XF, Fan XG, Huang Y, Zhang Y and Zhu C: Expression of cyclin D1 proliferating cell nuclear antigen in liver of C57BL/6 mice infected with Helicobacter pylori. World Chin J Digestol 14: 1341-1345, 2006

82. Zhang Y, Fan XG, Chen R, Xiao ZQ, Feng XP, Tian XF and Chen $\mathrm{ZH}$ : Comparative proteome analysis of untreated and Helicobacter pylori-treated HepG2. World J Gastroenterol 11: 3485-3489, 2005

83. Komatsu K1, Miyashita T, Hang H, Hopkins KM, Zheng W, Cuddeback S, Yamada M, Lieberman HB and Wang HG: Human homologue of S. pombe Rad9 interacts with BCL-2/BCL-xL and promotes apoptosis. Nat Cell Biol 2: 1-6, 2000.

84. Lin B, Kolluri SK, Lin F, Liu W, Han YH, Cao X, Dawson MI, Reed JC and Zhang XK: Conversion of Bcl-2 from protector to killer by interaction with nuclear orphan receptor Nur77/TR3. Cell 116: 527-540, 2004.

85. Hoetelmans RW: Nuclear partners of Bcl-2: Bax and PML. DNA Cell Biol 23: 351-354, 2004

86. Oltvai ZN, Milliman CL and Korsmeyer SJ: Bcl-2 heterodimerizes in vivo with a conserved homolog, Bax, that accelerates programmed cell death. Cell 74: 609-619, 1993.

87. Tsujimoto Y, Finger LR, Yunis J, Nowell PC and Croce CM: Cloning of the chromosome breakpoint of neoplastic B cells with the $t(14 ; 18)$ chromosome translocation. Science 226: 1097-1099, 1984.

88. Cleary ML, Smith SD and Sklar J: Cloning and structural analysis of cDNAs for bcl-2 and a hybrid bcl-2/immunoglobulin transcript resulting from the $\mathrm{t}(14 ; 18)$ translocation. Cell 47 : $19-28$, 1986.

89. Yang LJ, Cao XT and Yu LZ: Bcl-2 and Bax in apoptosis of tumor cells. Chin J Cancer Biother 10: 232-234, 2003.

90. Yin XM, Oltvai ZN and Korsmeyer SJ: BH1 and BH2 domains of Bcl-2 are required for inhibition of apoptosis and heterodimerization with Bax. Nature 369: 321-323, 1994.

91. Yang E and Korsmeyer SJ: Molecular thanatopsis: a discourse on the BCL2 family and cell death. Blood 88: 386-401, 1996.

92. Yang E, Zha J, Jockel J, Boise LH, Thompson CB and Korsmeyer SJ: Bad, a heterodimeric partner for Bcl-XL and Bcl-2, displaces Bax and promotes cell death. Cell 80: 285-291, 1995.

93. Cotran RS and Kumar V and Collins T: Robbins Pathologic Basis of Disease. 6th edition. W.B Saunders Company, Philadelphia, PA, 1998. 